\title{
Strategic Intelligence during Coin Detention Operations - Relational Data and Understanding Latent Terror Networks ${ }^{1}$
}

Spencer Willardson

Department of Political Science, 347 Schaeffer Hall, Iowa City, IA 52242, USA

Email: spencer-willardson@uiowa.edu

\begin{abstract}
One aspect of the global "War on Terror" that has received limited coverage in the academic literature is the problem of detained persons as it relates to intelligence. This is a surprising oversight, given the number of detainees that the US has been responsible for (over 25,000 were in custody in Iraq alone at one time during its peak). The detention environment offers a prime strategic intelligence opportunity for the US intelligence community to study the tactics and organizations of individuals who have been removed from the overall conflict. In this article an easily-implemented collection program is recommended to be deployed in US/Coalition detention centers. The primary recommendation is to gather relational data on detainee communication, both authorized and illicit, and to use this data to perform network analyses of terrorist groups and their individual members.
\end{abstract}

\section{Keywords: detention, networks, intelligence collection}

One of the themes of the War on Terror has been the difficulty of obtaining human intelligence about terror groups. This has been the refrain since the 9/11 Commission Report. The mission to kill Osama Bin Laden in May 2011 provided an example about the importance

\footnotetext{
${ }^{1}$ This is an Author's Original Manuscript of an article submitted for consideration in the Defense and Security Analysis (C) Taylor \& Francis; Defense and Security Analysis is available online at http://www.tandfonline.com 14751798.2013.760249. Available 28 January 2013.
} 
of cultivating capable human intelligence capabilities and utilizing intelligence networks to combat terrorism. In the aftermath of $9 / 11$, Krebs demonstrated that with a little bit of information it was possible to construct a picture of the $9 / 11$ groups of hijacker. ${ }^{1}$ This ex post examination of the evidence revealed in news stories was a proof of a concept of sorts, which pointed in the direction for future research by both social scientists and intelligence analysts in the ways that they both conceptualized the threat from terror groups and how they needed to gather information to detect, monitor, and defeat such groups.

The shift in battlefield focus from the US to Afghanistan to Iraq, and now back to Afghanistan has in some ways distorted understandings about the relationship between the tactical battles being fought in Fallujah (for example) and the overall mission of defeating transnational terror groups at home and abroad. In Iraq, for example, it was common to think of all the enemy combatants as insurgents and leave the classification there. This made sense from a tactical perspective, but from a strategic perspective it was not until the US command separated these groups and focused on defeating the groups associated with Al Qaeda in Iraq (hereafter AQIZ) that the tide of battle began to turn. ${ }^{2}$ It was US involvement with the Awakening Movement and the Sons of Iraq, coinciding with the troop "surge" and a change to a counterinsurgency strategy that brought violence down and allowed the US to withdraw from Iraq a few years later. ${ }^{3}$

One aspect of the "surge" was that the US increased both its commitment to, and capacity for, detaining suspected insurgents. At its peak during the "surge" the US was holding over 25,000 detainees. ${ }^{4}$ Most of these detainees were held at Camp Bucca in Southern Iraq. Camp Bucca and other similar detention facilities hold a deep latent potential to provide important information to analysts about the way that terror groups organize themselves and 
how members of these groups communicate with one another. These facilities can also provide an important way to discover members of terror groups in ways to allow for the goals stated above, i.e. to detect, monitor and defeat terrorist groups.

This article has two goals. The first is to demonstrate the potential of theater interment facilities to become hubs of intelligence collection on terror groups in non-intrusive, humane, and discreet ways. The second is to suggest concrete areas in which this potential can be exploited for the benefit of the US and its allies in the war on terror in its broader context.

It is organized as follows: in the first section a brief introduction to detention operations in Iraq is provided, with the focus on the large detention facility at Camp Bucca. This introduction includes a description of the camp and the processes at the Camp from open and unclassified sources. The second section examines areas where this detention environment can be useful for generating useful information. A third section suggests ways that information can be collected that maintain a strict separation of "intelligence" from the guard force, so as to avoid the pitfalls exposed in cases such as those at Abu Ghraib in 2003$04 .^{5}$

The fourth section identifies how the collected information can be used by analysts who are interested in the functions of the interment facility to enhance the ability of the guards to protect both the prisoners and each other, but especially to protect civilians and soldiers outside of the facility from harm by extremists. The fifth section details how the information can be translated into a tool for analysts in the larger strategic context (both in the theater of battle and worldwide) to detect, monitor, and defeat terrorists. The section that follows details some practical counter-intelligence considerations that will be necessary to 
ensure the success of the proposed collection and analytical program. The final section provides some conclusions and suggestions for further development of the ideas presented.

\section{Detention Operations in Iraq}

Detention operations in Iraq (and Afghanistan) have had a somewhat rocky history since the Iraq War began in 2003. The most notable example has been the troubled narrative of the events at Abu Ghraib. Besides being a public relations nightmare, the Abu Ghraib scandal provided ready fodder for extremist recruiters. ${ }^{6}$ Manifestly, Abu Ghraib was a strategic defeat for the US and its efforts in Iraq and elsewhere in the world to defeat terrorism. ${ }^{7}$ One of the consequences of these events was that the idea of tying intelligence operations to detention operations became a politically volatile proposition. The debates on the use of various interrogation techniques became wrapped up in the place in which those interrogations occurred. Those debates also touched on many jurisdictional matters over "ownership" of detention and the proper role of outside agencies and outside branches (in the case of intelligence) operating within interment facilities. ${ }^{8}$

One of the "solutions" to the problem of detention was to separate detainees into different populations - the few who would undergo interrogation and the many who would not. It is in this second population, - the detention centers for detainees who are not the target of intelligence scrutiny - that the latent potential to study terrorist networks and communications is perhaps most clearly evident. The primary function of such facilities is to protect civilians and soldiers in the conflict area from dangerous, or potentially dangerous, fighters. This function was evident in the practice during the "surge" in Iraq to detain individuals who were suspected of being dangerous for short periods of time - 90 days, for example. A second primary function of the detention facility was to protect the detainee 
population from acts of violence by other prisoners whilst a third primary function was to protect the guard force from violence by the detainee population.

During the "surge" in Iraq, the detention system - and the detention facility at Camp Bucca - took on a number of secondary functions. These revolved around a rehabilitation mandate to identify moderate detainees and to prepare them for release. These functions led to a detention process that became bifurcated in many ways and which required monitoring and an assessment of the detainee population. In this way, an intelligence function was brought back into the detention process. ${ }^{9}$ These principles were based on the Counterinsurgency (COIN) principles advocated by General Petraeus and his staff and who were the driving motivators of tactics and strategy during the "Surge" of 2007-08.

\section{The Utility of Detention Centers as an Information Source}

One of the overlooked aspects of detention centers has been that they provide an opportunity to observe social interaction between detainees in a way that can be recorded and measured. Detention facilities become a kind of social laboratory. The focus here is on the collection of relational and communications data as a means of studying the social structure of extremist groups and of discovering methods and patterns of communication between members of those groups. Other types of data gathering techniques at these locations may also help analysts understand extremist group recruitment and training techniques. There is evidence that US detention facilities in Iraq became centers for extremist group recruiting during the period of time it was running such centers. ${ }^{11}$ This led to many of the secondary functions of the detention - especially programs to help rehabilitate and re-indoctrinate detainees before they were released from the facility. ${ }^{12}$ 
The suggestion to study detained populations for information about relations among extremist group members and, even, relations between different extremist groups, is based on an assumption that within the detention environment there will be opportunities for detainees to communicate with one another in such a way as to be recorded. An underlying assumption to the collection of these data is that there is going to be a relationship between the way that members of extremist groups communicate on the outside and ways that they communicate within a facility. If anything, communication within a facility may be more revealing as the members of such groups will be concentrated in ways that are different than the typical "cellular" structure of many terror groups - especially those associated with Al Qaeda. ${ }^{13}$

Another assumption of this particular proposition is that there are authorized forms of communication between detainees located in different compounds or cell blocks within detention centers. Detainees within such facilities are segregated according to some criteria, and are located in different physical places. Communication between detainees in written form is typically authorized if there is some sort of relationship (normally kinship) between them. Kinship is a fuzzy concept that allows many detainees to find ways to communicate with each other in a way that may reveal latent group structures and dynamics.

A simple change to the way that guards carry out their clerical duties will allow a wealth of intelligence data to be captured. This change will help analysts learn about the patterns, volume, and target of various communications within the detainee population. There are a number of reasons why studying detainee populations for information about communications patterns and group structures is a strategic intelligence - as opposed to a tactical intelligence - activity. While such communications patterns may be an important source of information for those tasked with the primary purpose of protecting detainees and 
the guard force from violent elements, it is the larger patterns that such "tactical" communication provides that will provide information about the larger groups from which a sub-set of the detainee population comes.

Camp Bucca, for example, housed detainees from both the Sunni and Shi'a insurgencies throughout its operation. ${ }^{14}$ The Sunni insurgency, however, was not carried out by one group. The primary enemies to the US during the "surge" were members of Zarqawi's Al-Qaeda in Iraq (AQIZ). ${ }^{15}$ This group, although acting mostly independently, was affiliated to the larger Al Qaeda network of terror groups. ${ }^{16}$ Many of the higher ranking members of the group operating in Iraq were trained by Al Qaeda, so it is reasonable to assume that much of the training of the local members was in line with the training and operational doctrine of the overall Al Qaeda organization. This training would then also carry over into activities carried out by members of this group that were being held in detention facilities. Thus, the patterns of action and communication that are exhibited by detainees can be used as a template for identifying such communication and organizational structures of groups and members of groups that are still operating outside of detention. While this article does not explicitly explore the detention facilities being operated in Afghanistan, the same principles of pattern overlap could be used to examine the workings of different groups, such as the Taliban or the Haqqani network, who are the primary threats to US and NATO ISAF forces operating in that theater. $^{17}$

The structure of many US detention facilities (based on a Cold War design of prisoner of war camps) allows much autonomy and self-organization by detention populations. Another fruitful area of examination is the leadership structure that emerges in such situations. This particular aspect of potential intelligence is not explored this too deeply here 
because the study of such a structure may require more intrusive intelligence measures and would require more doctrinal changes. In general, such an avenue would ideally be explored. The focus here has been on the areas that can be exploited with a minimum amount of intrusiveness and without enmeshing intelligence personnel into the day-to-day operations of the detention center.

\section{Collecting Network Communication Intelligence in Detention Facilities}

One objective of this article is to suggest fruitful sources of strategic intelligence that are currently available to US intelligence agencies. One self-imposed condition of these suggestions is that they are implemented in a way that is compatible with current US detention doctrine. Current doctrine was revised after the events at Abu Ghraib in 2003 in which it seemed that intelligence operatives from various agencies had the run of US Army/military detention facilities and that there was little or no separation of detention from intelligence gathering. ${ }^{18}$ In the aftermath of these types of events, a number of changes occurred in the way that detainees, who were thought to have intelligence value, were treated, as opposed to detainees who were simply a security risk.

One key to the potential for intelligence gathering about extremist group networks in the larger detention facilities has to do with the size of the population. A large population in detention centers can be thought of as being a representative sample of some real population. That population might be exclusively composed of individuals who may be a threat to friendly forces or it might be a broader subsample from the entire population. Ideally, the detention population will include more of the former and be skewed toward more dangerous members of the population. Even within this "skewed distribution" of the overall population, however, there will be a range of extremism. Besides differing over the dimension of the 
extent to which a detainee is supportive of an extremist cause, detainees will also differ across the spectrum of capability in terms of training, education, access to group leadership, access to material goods, and other similar factors.

A detention facility should be equipped to monitor a number of activities associated with detention. It is this monitoring and recording that offers the potential for greater intelligence exploitation. This section details the type of information that can be collected as well as ways in which the information can be collected. As noted earlier, detention facilities typically allow for some sort of (even limited) communication between detainees. This communication can be recorded using existing detainee management practice or with the addition of a simple data base to the facility. The following information is likely to be of most use to analysts exploring extremist group communication dynamics.

The key item is the identity of the sender and receiver of any communication within the facility. Again, these communications are authorized communications that should be "delivered" using some existing system by the guard force. This communication is usually required to be in English and both the sender and receiver are required to have pieces of information to be able to use the system. By recording sender and receiver data, it is possible to begin to examine one communication network within the detention system. In addition to this most basic data, recording the date of the communication, the stated relationship (also required) between detainees and whether or not the message was allowed to be sent are recommended. There are a number of rules that govern inter-detainee communication, and noting whether or not a message was allowed to be delivered is a key piece of information. Ideally, each message would also be digitally recorded (i.e. a scan or photograph taken of the actual correspondence). If each message were catalogued in this manner, it would make 
future analysis much easier. The burden of scanning and maintaining may be prohibitive, but one alternative would be to give the records clerks a set of criteria to determine whether or not to make a scan of the correspondence. Some potential criteria include the following: whether a message has an attached photograph/letter from outside the detention facility; whether a message mentions specific dates; or whether a message appears to be altered in any way.

The downside of a selective scanning of correspondence comes from such criteria that are easy for untrained guards to reveal this information to detainees. Such a revelation defeats the purpose of collecting data in a non-obtrusive way and keeping the intelligence aspects of this proposed collection program outside of the actual detention center. By making this a clerical/book keeping exercise by the guards who are interacting with the detainees, the guards are shielded from any intelligence related fallout. This is an important bureaucratic point to make with the military commanders, who are tasked with running detention centers.

The fallout from Abu Ghraib (and even the Quran burning in Afghanistan) ${ }^{19}$ more recently makes detention operations a high risk/low reward environment. Efforts to "sanitize" the process of intelligence collection and enforce a strict separation of guard force and intelligence is an important design feature of a proposed program that consists of keeping track of the above information by the guard force. Such clerical work can easily be incorporated into standard operating procedures for handling detainee requests for communication. A simple form with the following information would be sufficient: sender; recipient; date; relation between sender; and receiver. Those tasked with maintaining information on detainees in the Detainee Management System (DMS), can easily add the information from the detainee requests for communication/forms for communication. ${ }^{20}$

\section{Utilizing the Collected Communications Information}


At least two basic ways exist to utilize the collected information about detainee communication. The first of these is to use the data proactively to look for patterns within the detainee populations. This is an application that fulfills the strategic potential of the intelligence program that has been set to collect information on the structure of a terror group communication network. Identifying the larger macro patterns of communication within the detainee population could then be used to examine other larger populations. The second application of the data is more reactive in the sense of exploring the relations of detainees that are being targeted for intelligence investigation. The focus here is on the first approach to utilizing the data, but it will also note the ways in which these data can be used as part of more traditional targeted analysis of detainees within the population.

In order to illustrate the potential for this methodology a number of hypothetical network datasets have been created for a small detainee population $(n=20$ for each of the hypothetical networks). These communication data represent the fraction of detainees that will attempt to communicate with other detainees while in custody. That is to say, if 25 percent of the detainee population attempted to communicate over the period of one month, it would represent a total detainee population of 100. Not including in these example datasets are the "isolates", or detainees, that did not attempt to communicate with any other detainee.

\section{Figure 1}

\section{Hypothetical Detainee Communication Networks}



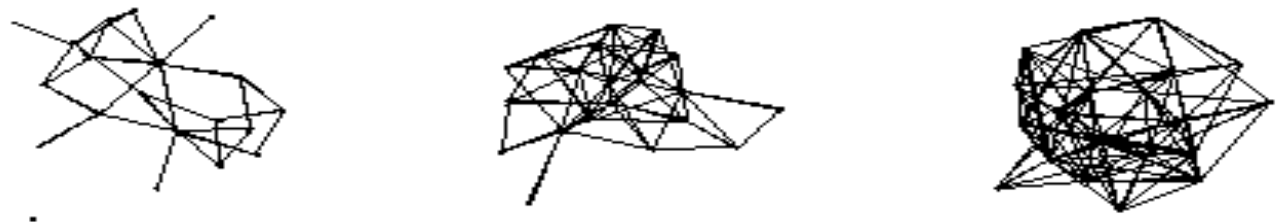

The three random networks are shown in Figure 1. They stylistically represent a type of control to a hypothesized communication network for a group of extremist detainees. A random structure can be used to compare against an actual network to look for irregularities. Various statistical routines have been developed to make such comparisons. ${ }^{21}$

The pattern that most interests the analyst would be one in which a clear communication hub emerges, with one detainee, or a small group of detainees, handling the correspondence for large numbers of extremist detainees. Such a pattern would be visible to an analyst looking at these communication data if a simple routine were set up to count the number of communications per detainee (outgoing and ingoing) and which flagged detainees that passed a certain threshold. A detainee who had a total of five communications in a month-long period, for instance, would be flagged for further investigation. This analysis 
would ideally be undertaken at a remote site by analysts who were not in physical contact or proximity to the detained individuals.

A second proactive measure would be to flag all communication that has any sort of "attachment". As discussed above, any attachment should be noted and scanned. Ideally, all communication would be scanned as well, but any photographs or letters from home have the possibility of containing hidden information. From an intelligence gathering perspective, the ability to flag and analyze all outside correspondence to look for patterns and to seek to identify possible coded information would be of great value to the overall effort to penetrate the communications networks of insurgent groups operating outside of the detention environment.

A third proactive measure would include a way for analysts to flag any correspondence coming to or from a detainee who has been flagged. This would allow analysts to receive an alert when any detainee they determine to be of interest sends or receives communications. These flags would be invisible to the DMS operator and would only be generated on the back end of the database. This third measure is a kind of hybrid between the proactive and reactive analytical tools available to examine these networks. The collection method and infrastructure identified above allows a great deal of information to be collected and lets analysts look for communications patterns ex post in the case of any sort of incident with a detainee. Such a check of communications would be an important addition to any sort of investigation of detainee misbehavior.

That is the essence of the entire proposed collection and analysis program advocated in this article - to provide information to the analysts who are seeking to understand the 
behavior and motivation of detainees specifically, and who have that information available as a resource for those that are looking at extremist group communication behavior more widely. The reactive use of collected intelligence is fairly straightforward. The database of communications would be available for searching functions. It becomes a resource for analysts who are conducting investigations or building products (such as overviews). The collected data would reside in a database with a number of search and report functions to make the information easily available to analysts as they do their work. There are a number of potential ways that this communication information can be used to look for macro trends over the entire detention center or to investigate the behavior of individual detainees.

Consider the case of a detainee who has been caught or is suspected of performing some act of interest. This act may be violence against another detainee, breaking communications rules, threatening the guard force, or even offering to share information with coalition forces - the types of incident that are of interest are potentially very wide-ranging. Once an individual detainee has been identified as being the subject of analysis, the available database of communication can easily be used to provide an overview of the detainee's personal network.

Figure 2 shows the ego-centric network of a fictional detainee who is the subject of an investigation. It would be quite easy to create a report function that generates a report and a graphic like Figure 2 automatically by simply selecting a detainee by identification number. The potential for this intelligence to help in investigations is quite powerful. By linking individual detainees by their communication it becomes possible to explore whether groups are operating in a coordinated manner while they are in a detention setting. If such coordination is taking place, the collected information on these communications will provide 
a way to monitor and exploit it in a way that helps the guard force better carry out its primary tasks.

The second example of a reactive use of this collected intelligence is the use of the communication information to examine macro communication trends. Initially trends would be examined after a major incident (such as a riot, a fight, an escape attempt, etc.) takes place $^{22}$. The communication data can be examined to look for spikes in communication, changes in patterns, which detainees were communicating in the period leading up to the incident, etc. The most immediate use is similar to the first example above, i.e. using the data to put together a retrospective report on an event that has already occurred. However, if trends are identified in the way that detainees communicate in the period leading up to major incidences, then such information can be used as warning intelligence ${ }^{23}$ to build lists of indicators that can be turned into algorithms to monitor the communication data. In this way the reactive analysis leads to the creation of proactive tools to monitor and alert when changes to the communications patterns indicate that a major incident is possible/imminent.

\section{Using this Intelligence in the Larger Strategic Context}

The previous section detailed the ways in which the collection of communication data can quickly become an asset to those working in large detention facilities. This collected intelligence is of obvious value to helping US soldiers in their primary missions within the detention facility. If those were the only benefits, then this suggested course of intelligence collection would be valuable. There is, however, an even larger potential scope for this information to be used by strategic analysts who are interested in defeating and disrupting extremist groups. 
The potential applications for strategic intelligence are much more speculative than the applications discussed above. One potential criticism of this approach is that the behavior of extremist group members will necessarily be different under conditions of detention. That is a valid concern for the applicability of studying the communication network of detained individuals and trying to make inferences about common features of communication during detention and communication "in the wild." The argument that I make concerning the potential for strategic intelligence applications of this intelligence collection program are based on a few assumptions that are based on other documented factors of extremist group behavior while detained.

The main assumption of this argument is that (despite the best efforts of US forces) many detainees will not be reformed by detention. Reformation became an important part of the strategy of US detention efforts during the Surge in Iraq ${ }^{24}$, and some evidence exists that these efforts were successful. However, making these efforts to reform detainees also allows true extremists the opportunity to "hide in plain sight" and be seen as reforming, if it will allow them immediate and future benefits. Immediate benefits may be improved conditions and privileges during their detention. Future benefits may include an early release from detention.

Members of extremist groups then have an incentive to appear to reform. Leaders of these groups have an incentive to ensure that the members of the group who are in detention do not reform. These groups do not want to lose strength nor do they want to lose the investment that has been made in training and indoctrinating members of the group ${ }^{25}$. These two competing incentives provide a solid theoretical possibility that group leaders will attempt to communicate with members in a way that ensures their subordination and their 
loyalty to the group in the future. This communication cannot be overt, especially as the leaders of the group have the same incentives to appear to reform as the rank and file members with whom they are communicating.

The situation that arises from these competing incentives mimics, to some degree, the challenges that are faced by extremist groups in the population at large. In order to operate, these groups must not be captured or killed, requiring them to blend in with the population. In order to communicate without revealing true intentions, these groups utilize numerous methods of legitimate communication with various ways of encoding their intended message. It is reasonable that in conditions of detention the legitimate forms of communications will be "co-opted" by extremists to pass messages that are innocuous. It is also likely that the tradecraft used by such detained extremist group members will be similar to the tradecraft used to communicate by various means outside of detention.

This is why it is preferable that all detainee communication be logged and a picture taken of the communication. By examining the overall patterns of communication and then utilizing various techniques it is possible that analysts can uncover communication methodologies that can be used to disrupt the communication of these groups in the future. In addition to the strategic potential of the collected communications data as a means of exploring patterns these data can also be linked to contact and communication that takes place outside the detention system. In the case of Iraq, detainees were allowed visits from family members under certain conditions ${ }^{26}$. These visits provide the opportunity to exchange information from the outside groups that are still operational outside of the detention facility and the members of the group that wish to maintain contact. In the case of group leadership, it is possible that the internal communications network can be exploited along with the outside 
visitation to create the opportunity to "run" an extremist network from within the confines of the detention system. Such an outcome would be perverse in its effect - immunizing leaders from the dangers inherent in their activities.

One way to attempt to counter this possible threat is to proactively monitor visitations between detainees and outsiders (which must be relatives of some sort or another of the detained individual) - and to simultaneously examine the communications patterns of detainees that are being vetted for the privilege of receiving visitors. This would be a special case of examining the communication pattern of detainees who preparing for visitation by looking for patterns.

Figure 2 illustrates this targeted examination of detainees. The figure shows a hypothetical detainee, D1, who in the week prior to visitation received a communication from detainee D2. D2 has received communication from a number of individuals D3, D4, D5, and D6. Three of these four detainees are in a special monitoring category for individuals who are suspected of maintaining activity in an extremist group. Both D2 and D1 have not been monitored prior to this pre-visitation check. In light of this information it is likely that these individuals may need to be placed under closer analytical scrutiny, and it is possible that the visitation between detainee D1 and the outside visitor will need to be monitored and analyzed. If the communication has been visually captured (photographed or scanned) then these pieces of communication can be further scrutinized.

\section{Figure 2}

\section{Targeted Detainee Egocentric Communication Network}




\section{Hypothetical Communication Network Detainee (D1) as Intelligence Target}

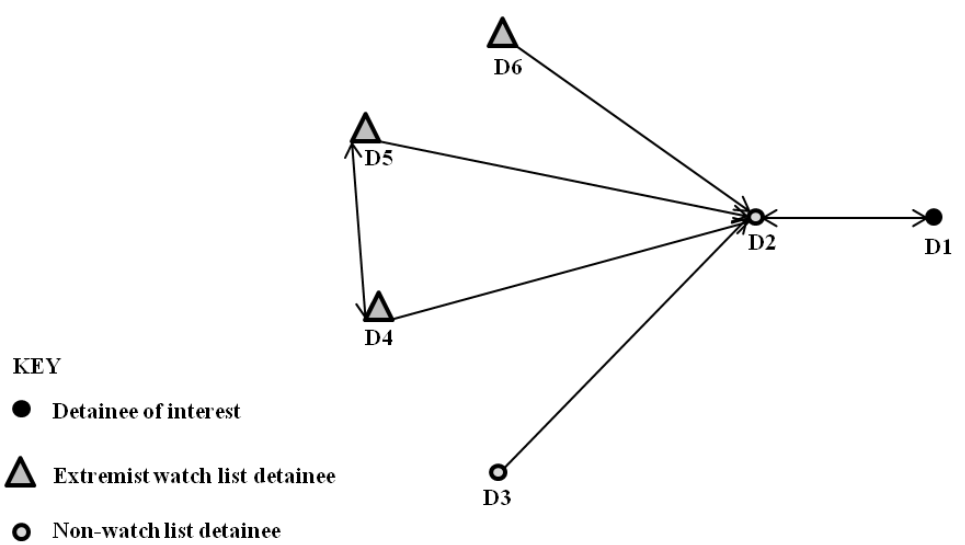

\section{Counterintelligence Considerations}

This entire collection program has been designed around the principle that the guard force should be hands off in the intelligence gathering process within detention facilities. This keeps a proper distance between operations and intelligence that prevent any appearance of impropriety in guard force actions that could lead to an Abu Ghraib-type incident. This approach also has a practical counterintelligence component to it. Detainees must see the guard force as a fair (and possibly neutral) party who simply perform its functions of maintaining the routine and providing safety and discipline to the detainee population. By keeping the guard force role to a minimum - essentially clerical activities - on the collection end, this relationship between the guard force and the detainees can be maintained. More importantly, the guard force, untrained in intelligence collection and counter-intelligence will not have to receive any special training in dealing with this data. In addition, there will be a 
much smaller chance that communications networks are being studied will be revealed, inadvertently, to the detainee population.

This is why it is important to maintain the analysis and targeting based on this intelligence at a level higher than the detention guard force authority. The best system would be to establish an independent analytical cell that handles the analysis and monitoring at the facility level. The data would also be made available to national agencies to use in the more strategic manner outlined above. This network data would be maintained (and likely kept anonymous) for the consumption of higher level analysis, in order to protect the data as well as its source and method of collection.

\section{Concluding Thoughts}

Detention operations in Iraq and Afghanistan have been highly visible throughout the course of those conflicts. This visibility has mostly been the result of unfortunate events. The latest 'gaffe' involving the burning of Qurans from the detention facility in Kandahar is simply the latest iteration of this trend. Detention operations in Iraq ceased with the US withdrawal at the end of 2011. The question of detention in Afghanistan is one that is very much under review, with the bulk of prisoners likely to be transferred to the custody of the Afghani government in the near future.

These circumstances render the suggestions of this article somewhat theoretical and abstract. Detention facilities can be the source of powerful intelligence information in ways that are different from the typical interrogation exploitation model of intelligence collection which have been the norm. This is an important point of consideration both in the present and in future conflict. In designing training and doctrine for dealing with those who have been 
removed from the conflict and who are being held in custody, the integration of such intelligence collection capabilities should not be overlooked.

The approach taken regarding the detention of individuals has evolved considerably over the course of the conflict. ${ }^{27}$ It is probable, however, that the system that will be in place at the beginning of the next conflict will be based on the experiences and lessons learned of the current detention system. This provides an excellent opportunity for the intelligence community to work with the Military Police to implement an approach such as the one outlined in this article to take advantage of the information that is available for exploitation at a low cost.

The continued conflict in Afghanistan means, however, that the suggestions made here do not need to be "tucked away" for later. The principles of intelligence collection based on current detention practices can be added to the tool kit of those that are working in detention operations as long as the US is operating such facilities ${ }^{28}$. This is not any different than the changes made in capture standards, release boards, and those other innovations that have come from the legal standpoint.

\section{Notes}

$1 \quad$ Valdis E. Krebs, "Mapping Networks of Terrorist Cells," Connections Vol. 24, No. 3 2002: $43-$ 52.

2 cf. Ahmed S. Hashim, Insurgency and Counter-Insurgency in Iraq Ithaca, Cornell University Press, 2006, 46.

3 Kimberly Kagan, The Surge: A Military History, 1st American ed. New York: Encounter Books, 2009; Michael Greenstone, "Is The 'Surge' Working? Some New Facts," SSRN eLibrary September 14, 2007, http://papers.ssrn.com/sol3/papers.cfm?abstract_id=1014427+; Barry S. Di Ruzza, "The 'Surge' in Iraq, a Center of Gravity Perspective” Kingston RI, Naval War College, 2008, http://www.dtic.mil/cgiin/GetTRDoc?AD=ADA494414\&Location=U2\&doc=GetTRDoc.pdf.

$4 \quad$ See for example Michael E. Hanlon and Jason H. Campbell, "Iraq Index: Tracking Variables of Reconstruction and Security in Post-Saddam Iraq" Washijgton DC, Brookings Institution, 4 June 2009, http://www.brookings.edu/iraqindex.

5 James F. Gebhardt, The Road to Abu Ghraib: US Army Detainee Doctrine and Experience Darby, PA, DIANE Publishing, 2005; David P. Forsythe, The Politics of Prisoner Abuse: The United States and Enemy Prisoners After 9/11 Cambridge, Cambridge University Press, 2011; 
David P. Forsythe, "United States Policy Toward Enemy Detainees in the 'War on Terrorism'," Human Rights Quarterly Vol. 28, No. 2 2006: 465-491.

$6 \quad$ Camp Bucca had become a "Jihadist University" according to Nic Robertson, "Behind the Scenes: Walking Amid 2,000 Al Qaeda Suspects - CNN.com,” News, CNN, April 28, 2008, http://www.cnn.com/2008/WORLD/meast/04/28/btsc.iraqprison/index.html?iref=newssearch; see also Alissa J. Rubin, "Critics See Progress at US Jails in Iraq - The Boston Globe," News, Boston.com, June 2, 2008, http://www.boston.com/news/world/middleeast/articles/2008/06/02/critics_see_progress_at_us_ja ils_in_iraq/.

$7 \quad$ Gebhardt, The Road to Abu Ghraib. Darby, DIANE Publishing, 2005.

$8 \quad$ Forsythe, "United States Policy Toward Enemy Detainees in the "War on Terrorism" Human Rights Quarterly Vol. 28, No. 2 2006: 465-491. in particular attacks the idea of interrogation within detention centers. Robertson, "Behind the Scenes: Walking Amid 2,000 Al Qaeda Suspects - CNN.com" Major General Stone who oversaw detention activities during the Surge made Counterinsurgency Operations within the detention process a key element of his program. G. D.H Petraeus, "Report to Congress on the Situation in Iraq," Testimony Presented Before the House Subcommittee on International Relations on 10-11 September 2007 (2007), http://www.dtic.mil/cgi-bin/GetTRDoc?AD=ADA473579\&Location=U2\&doc=GetTRDoc.pdf; Thomas E Ricks, The Gamble: General David Petraeus and the American Military Adventure in Iraq, 2006-2008 New York: Penguin Press, 2009. Robertson, "Behind the Scenes: Walking Amid 2,000 Al Qaeda Suspects - CNN.com"; Alissa J. Rubin, "Critics See Progress at US Jails in Iraq - The Boston Globe," News, Boston.com, June 2, 2008, Rubin, Alissa J. Rubin, "Critics See Progress at US Jails in Iraq - The Boston Globe," News, Boston.com, June 2, 2008, Jonathan David Farley, "Breaking Al Qaeda Cells: A Mathematical Analysis of Counterterrorism Operations (a Guide for Risk Assessment and Decision Making)," Studies in Conflict and Terrorism Vol. 26, No. 6 2003: 399-411; Gaetano Joe Ilardi, "Al-Qaeda's Counterintelligence Doctrine: The Pursuit of Operational Certainty and Control," International Journal of Intelligence and CounterIntelligence 22, No. 2 (2009): 246; Valdis E. Krebs, "Mapping Networks of Terrorist Cells," Connections Vol. 24, No. 3 2002: 43-52. "FOIA 09-F-1797 Religion Report", June 29, 2011. This document was obtained using a freedom of information request to CENTCOM and took over two years to process. I have a breakdown of the religion of all captured detainees from April 2003 to August 2008 in the Iraq Theater of war. Barry S. Di Ruzza, "The 'Surge' in Iraq, a Center of Gravity Perspective" Kingston RI, Naval War College, 2008, http://www.dtic.mil/cgiAhmed S. Hashim, Insurgency and Counter-Insurgency in Iraq Ithaca, Cornell University Press, 2006. Mark Mazzetti, Scott Shane and Alissa J. Rubin, "Brutal Haqqani Clan Bedevils US in Afghanistan," The New York Times, 24 September 2011, sec. World / Asia Pacific, http://www.nytimes.com/2011/09/25/world/asia/brutal-haqqani-clan-bedevils-united-states-inafghanistan.html. Gebhardt, The Road to Abu Ghraib; Macedonio R. Molina, "Detainee Operations: Defeating an Insurgency from Within the Wire" US Army Command and General Staff College, 2007; J. L Lightner, Voyage to the Dark Side: The Tortured Path of United States' Detainee Interrogation Policy, Master's Project Army War College, Carlisle Barracks, PA, 2007, Google Scholar.

Alissa J. Rubin, "Koran Burning at US Base Incites Afghans For 2nd Day," The New York Times, February 22, 2012, sec. World / Asia Pacific,

http://www.nytimes.com/2012/02/23/world/asia/koran-burning-in-afghanistan-prompts-secondday-of-protests.html; "Six Dead in Afghan Koran Protests," BBC, 22 February 2012, sec. Asia, http://www.bbc.co.uk/news/world-asia-17123464; "Afghan Anger Over Koran Burning an Emblem of Nation's Culture War," Los Angeles Times Articles, n.d., http://articles.latimes.com/2012/feb/25/world/la-fg-afghanistan-koran-20120226. 

operations/ Connectivity problems within DMS and with other applications (BATS) should be addressed as well, but that is beyond the scope of this particular proposal. For a basic understanding of the logic see: Carolyn J Anderson, Stanley Wasserman, and Bradley Crouch, "A P* Primer: Logit Models for Social Networks," Social Networks Vol. 21, No. 1 January 1999: 37-66; For a more topical discussion of the network problem in terrorism see: Walter Enders and Xuejuan Su, "Rational Terrorists and Optimal Network Structure," Journal of Conflict Resolution Vol. 51, No. 1 2007: 33; Steven M. Goodreau, James A. Kitts, and Martina Morris, "Birds of a Feather, or Friend of a Friend? Using Exponential Random Graph Models to Investigate Adolescent Social Networks" Vol. 46, No. 1 February 2009: 103-125; Miranda J. Lubbers and Tom A.B. Snijders, "A Comparison of Various Approaches to the Exponential Random Graph Model: A Reanalysis of 102 Student Networks in School Classes," Social Networks Vol. 29, No. 4 October 2007: 489-507. Unfortunately such incidents have occurred at US detention camps in Iraq. See for example: "Escape Tunnel Found at Iraqi Prison," CNN Iraq, 25 March, 2005, http://articles.cnn.com/2005-03-25/world/iraq.tunnel_1_escape-tunnel-camp-bucca-iraqiprison?_s=PM:WORLD; "US Troops Fire on Prison Riot as 4 Die," $C N N$ Iraq, 31 January 2005, http://articles.cnn.com/2005-01-31/world/iraq.prison_1_prison-riot-camp-bucca-prisoncamp?_s=PM:WORLD. Cynthia Grabo, Anticipating Surprise: Analysis for Strategic Warning Washington D.C.: Center for Strategic Intelligence Research Joint Military Intelligence College, 2002. "Iraqi Detainees 'Refusing to Go Home'," News, Healdsun.com.au, March 24, 2008, http://www.news.com.au/heraldsun/story/0,21985,23421977-5005961,00.html; Alissa J. Rubin, "Critics See Progress at US Jails in Iraq - The Boston Globe," News, Boston.com, 2 June 2008, Martha Crenshaw, "Theories of Terrorism: Instrumental and Organizational Approaches," Journal of Strategic Studies Vol. 10, No. 4 1987: 13-31 provides a wide-range of explanations for terror group behavior and terror group dynamics.

26 Corey Flintoff, "US Tries for Better Conditions at Iraq Prison Camp," NPR.org, January 31, 2008, http://www.npr.org/templates/story/story.php?storyId=18575320.

27 Robert Chesney, "Iraq and the Military Detention Debate: Firsthand Perspectives from the Other War, 2003-2010", 13 October 2010, http://papers.ssrn.com/sol3/papers.cfm?abstract id=1690513.

${ }^{28}$ It seems as if the end of US detention operations may come sooner rather than later on the Afghan front. The Afghan government has called for the US detention centers to be turned over to them. "Afghans Demand U.S. Hand Over Its Major Battlefield Prison | Danger Room | Wired.com." Danger Room. Web. 25 Nov. 2012.

"The Increasingly-Uncertain Fate of Long-Term Military Detention in Afghanistan." Lawfare. Web. 25 Nov. 2012. 